\title{
On the Water Temperatures of Some Irrigation Water-Ways
}

\section{Hideo FUKUI}

The termperature of irrigation water is one of the unnegligible causes bringing with them areal differences in productivity-especially at the time of the damages by cool weather in summer,-observed in the paddy-field areas in Northeastern Japan. Not a few studies on the temperatures of river water have lately been progressing, but that on irrigation water-above all its actual state-have seldom been dealt with, there being hardly any results obtainable. How does the actual water temperature-change in response to the air temperature or the distance the water covers? The water-ways where the observation was carried out are in the areas subject to the cool damages, but were not selected according to any systematic plan with respect to the above-mentioned theme. The water-ways are not homogeneous in reality, but are conditioned by various complex interrelation of the quantity of running water, their inclination, their forms and structures, etc, which change the water temperatures, . and give much difficulty in the theoretical studies. But the actual state of the water temperatures in the actual water-ways seems to be necessary to be grasped in order to form the plans for reclamation and the improvement of productivity.

\section{The brief description of the chosen water-ways and their location.}

The surveyed water-ways are the following two main ones, which irrigate the lower reaches of the River Aka, Yamagata Pref., and the River Waga, Iwate Pref. (Fig. 1)1.

1. River Syôryuji This is branched off the R. Aka near its outlet to the Shônai plain by means of a sluice-gate. Its whole length is $21 \mathrm{~km}$; the largest discharge about $9 \mathrm{~m}^{3} / \mathrm{s}$; and the area of irrigation about 5300 ha, the Uchi river being tributary to it at a point about $3.5 \mathrm{~km}$ from the sulice gate. The main canal and the Uchi river flow down a gently sloping alluvial fan to Tsuruoka City, but from there downwards the main canal runs on a flat plain and irrigates the area of its left bank with a help of pumps. The Oyama river runs northwards at a distance of about $6 \mathrm{~km}$ from the lower reaches of the R. Shôryuji. The river gathers the drained water of the right side area and irrigates the left side area with a help of pumps. The both side areas of the rivers are about $1-4 \mathrm{~m}$ above the water surfaces of them, 


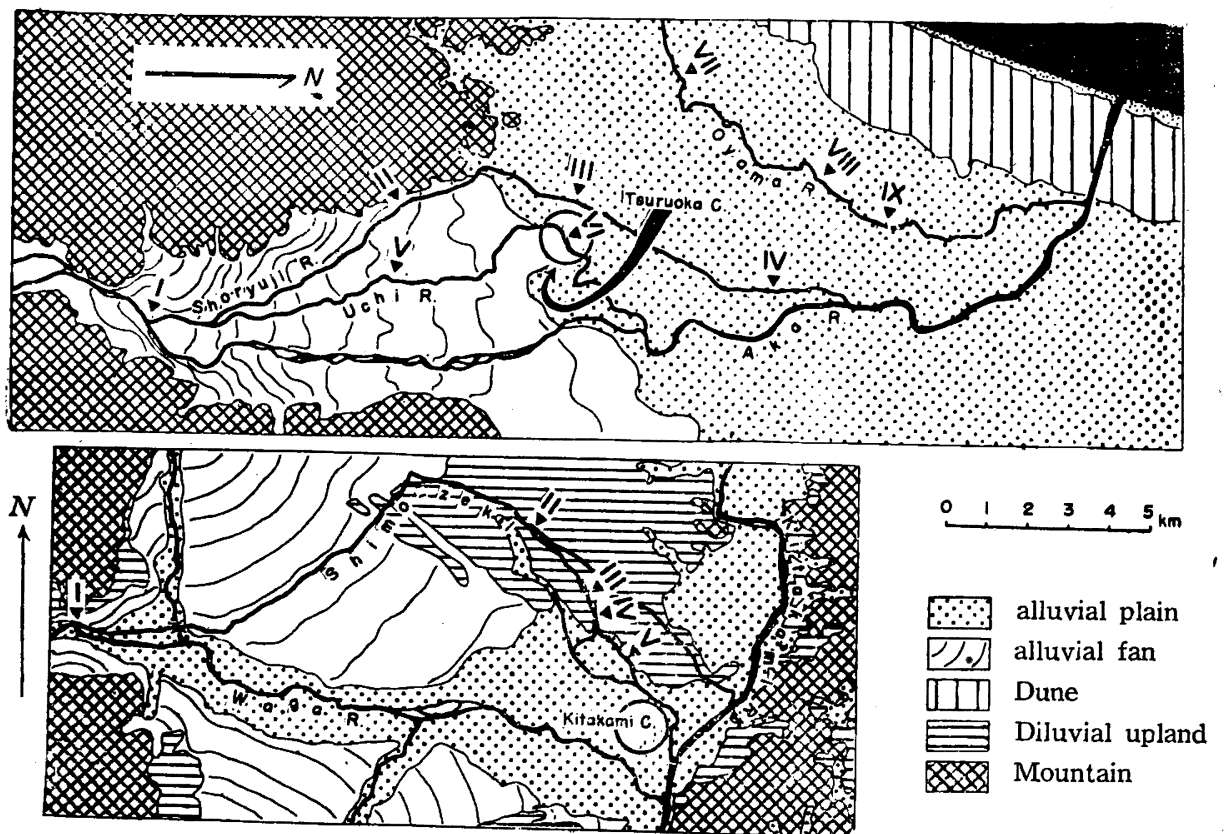

Fig. 1

and the walls and bottoms, of the rivers are scarcely protected from the groundwater flowing in.

2. Shimo-zeki (Shimo-canal) This is a water-way from the Ishibane Dam constructed at the outlet of the Waga River to the Kitakami valley plain. The largest discharge is $9.5 \mathrm{~m}^{3} / \mathrm{s}$; The whole length $25 \mathrm{~km}$; it runs down a pervasive fan and a diluvial upland, irrigating about an area of 3500 ha. This water-way is part of the main one from Point I to Point II, where it is branched off, and decreases in discharge, irrigating the diluvial upland. It passes Point IV located in a disected valley, and flows out under the upland, where it is divided into two, and then runs to Point V. The discharge decreases from Ptoint I to Point III, while it increases from the point downwards.

\section{The method of observation}

Each observation point is shown in the index map. Concerning the main water-way of Shôryûji and the Uchi river, the observation was carried out on August 3rd and 4th, 1956, and in the case of the Oyama river, on August 6 th and $7 \mathrm{th}$, the time being respectively from $12 \mathrm{~h}$ to $9 \mathrm{~h}$ on the following day, at an interval of 30 minutes except during the night. Shimo-zeki was surveyed on July 30 th and 31 st, 1955, from $12 \mathrm{~h}$ to $17 \mathrm{~h}$ on the next day, and at an interval of 4 hours at the longest in the night. It was very fine on all the days, and there was no rainfall higher than $10 \mathrm{~mm}$ on the previous 3 
Table I

\begin{tabular}{|c|c|c|c|c|c|}
\hline Canal & $\begin{array}{c}\text { Observation } \\
\text { Point }\end{array}$ & $\begin{array}{c}\text { Distance from } \\
\text { Sluice Gate } \\
\text { Km }\end{array}$ & $\begin{array}{c}\text { Supposed } \\
\text { Discharge } \\
\mathrm{m}^{3} / \mathrm{s} \\
\end{array}$ & $\begin{array}{c}\begin{array}{c}\text { Supposed } \\
\text { Velocity } \\
\mathrm{m} / \mathrm{s}\end{array} \\
\end{array}$ & $\begin{array}{l}\text { Time } \\
\text { Spent } \\
\text { hour }\end{array}$ \\
\hline \multirow{4}{*}{$\begin{array}{c}\text { SHORYUJI } \\
\text { R. }\end{array}$} & I & 0.0 & 8.5 & $-\quad \because$ & $\therefore$ \\
\hline & II & 7.4 & 6.4 & $(1 \cdot I l) \quad 1.43$ & 1. 45 \\
\hline & III & 12.4 & - & (II.1II) $\quad 0.86$ & 3.03 \\
\hline & IV & 18.1 & - & (III•IV) 0.3 & 8. 31 \\
\hline \multirow{3}{*}{ UCHI R. } & V & 6.8 & 1.1 & $(\mathrm{I} \cdot \mathrm{V})$ & 1.71 \\
\hline & VI & 12.2 & - & $(\mathrm{V} \cdot \mathrm{Vl}) \cdot 0.71$ & 3. 82 \\
\hline & \multicolumn{5}{|c|}{ Air Temperature at Point II } \\
\hline \multirow{4}{*}{ OYAMA R. } & VII & 0.0 & - & - & - \\
\hline & VIII & 5.9 & 3. 2 & $(V I I \cdot V I I I) 0.55$ & 2.97 \\
\hline & IX & 8. 3 & - & $(\mathrm{VIII} \cdot \mathrm{IX}) 0.65$ & 4. 01 \\
\hline & \multicolumn{5}{|c|}{ - Air Temperature at Point VIII } \\
\hline \multirow{7}{*}{ SHIMO-ZEKI } & I & 0.0 & 7.2 & \multirow{6}{*}{$\begin{array}{cc}(I \cdot I I) & 0.52 \\
- & \\
(I I \cdot I V) & 0.56 \\
(I V \cdot V) & 0.77\end{array}$} & - \\
\hline & II & 13.4 & 3.1 & & 7.16 \\
\hline & & 13.4 & 0.8 & & 7. 16 \\
\hline & III & 14.9 & 0.2 & & 7.90 \\
\hline & IV & 15.9 & 0.3 . & & 8.40 \\
\hline & V & 17.1 & 0.3 & & 8. 81 \\
\hline & \multicolumn{5}{|c|}{ Air Temperature at Point III } \\
\hline
\end{tabular}

days. The items of observation are the water temperature, the air temperature at $1 \mathrm{~m}$ above the water-surface, and the supposed water velocity and discharge. Moreover, with respect to water and air temperature, their values at each time were got from the curve of the daily change, and times spent in passing the points, from the mean water-velocity between the two points. As was shown by Prof. Asai, (1) the water temperature of river water is grasped as the change brought about by the movement of a water mass, and it seems that the irrigation water temperature is necessary to be observed from the same view-point. But the small-scale water-ways were observed according to the above method, because no suitable method for the survey could be obtained in this case.

\section{The results of the observations and their consideration}

Table 1 shows the general result of the observations. The daily variations of the water temperature are got on two co-ordinates; the $\mathrm{X}$-axis indicates time and the $\mathrm{Y}$-axis temperature in one of them (Fig. 2) and the $\mathrm{X}$ -

(1) T. Asai; The results of water-temperature in the River Ooi observed on a raft. Miscell. Rep. Res. Iast. for Nat. Res. No. 25, 1952 


\begin{tabular}{c|c|c|c|c|c}
\hline $\begin{array}{c}\text { Maximum } \\
\text { Temperature } \\
{ }^{\circ} \mathrm{C}\end{array}$ & $\begin{array}{c}\text { Time of its } \\
\text { Appearance } \\
\text { Time }\end{array}$ & $\begin{array}{c}\text { Minimum } \\
\text { Temperature } \\
{ }^{\circ} \mathrm{C}\end{array}$ & $\begin{array}{c}\text { Time of its } \\
\text { Appearance } \\
\text { Time }\end{array}$ & $\begin{array}{c}\text { Dlurnal } \\
\text { range } \\
{ }^{\circ} \mathrm{C}\end{array}$ & $\begin{array}{c}\text { i Date of } \\
\text { Observation }\end{array}$ \\
\hline 21.5 & 14.30 & 18.8 & $4.00 \sim 5.30$ & 2.7 & \\
22.8 & 15.40 & 16.9 & $4.30 \sim 6.10$ & 2.9 & August \\
23.7 & 15.15 & 20.5 & $4.30 \sim 6.00$ & 3.2 & 3rd and 4th, \\
25.5 & 15.15 & 22.3 & $4.00 \sim 4.30$ & 3.2 & \\
23.3 & 14.30 & 20.0 & $4.30 \sim 5.30$ & 3.3 & \\
$25: 0$ & 16.00 & 21.1 & $5.45 \sim 7.15$ & 3.9 & \\
\hline 32.1 & 13.15 & 25.0 & 8.00 & 7.2 & \\
\hline 26.9 & $17.00 \sim 20.00$ & 24.7 & $43.0 \sim 8.30$ & 2.2 & \multirow{2}{*}{ August 6th } \\
26.0 & $17.30 \sim 18.30$ & 23.7 & $6.00 \sim 8.30$ & 2.3 & and 7th, 1956 \\
27.6 & 17.00 & 24.6 & $5.30 \sim 7.00$ & 3.0 & \\
\hline 29.9 & 13.00 & 20.8 & 5.00 & 9.1 & \\
\hline $25.6(25.8)$ & $15.30(16.00)$ & 24.3 & 4.30 & $1.3(1.5)$ & \\
$27.2(27.2)$ & $15.15(15.15)$ & 23.9 & 5.15 & $3.3(3.3)$ & \multirow{2}{*}{ July 30th } \\
- & - & - & - & - & and 31st, 1955 \\
$28.5(28.5)$ & $14.00(13.15)$ & 23.8 & $4.00 \sim 6.40$ & $4.7(4.7)$ & \\
$27.9(28.1)$ & $14.15(14.30)$ & 23.4 & 5.00 & $4.5(4.6)$ & . \\
$27.5(27.8)$ & $14.30(15.00)$ & 223 & 4.30 & $5.2(5.8)$ & \\
\hline 33.6 & $14.00(13.15)$ & 21.8 & 4.30 & 12.7 & \\
\hline
\end{tabular}

axis time and the $\mathrm{Y}$-axis the distance from the sluice-gate in the other. (Fig. 3). The latter also shows the temperature variation at each observation point the time when a water mass, passing the sluice-gate at each time, arrives respectively at every point in the down-stream. Consequently, from Fig. 3 can be drawn a curve of the water temperature variations with the distance the water mass covers (Fig. 4), and can further be got the difference of water temperature, for every water mass, between the value at the sluice-gate of the uppermost point and that at every point in its downstream. (Fig. 5)

1. The Shoryuji and Uchi rivers (a) The rise is rapid from the lowest value to the highest one in the curve of the daily change, while the decline is execessive at Point $\mathrm{I},(15-18 \mathrm{~h})$, and gentle at the points in the lower part. (b) The minimum water temperature appers earliest at Point I, latest at Point II, and those at Point III and IV comes between Point I and Point II. In the case of the R. Uchi, on the contrary, it appears later downwards and the difference of time in appearance is one hour and a half between at Point I and at Point VI. (c) The maximum and minimum water temperatures are more excessive in the lower part; Point IV is $4^{\circ} \mathrm{C}$ higher than Point I in the maximum temperature, and is $3.5^{\circ} \mathrm{C}$ higher in the minimum. (d) The lower 

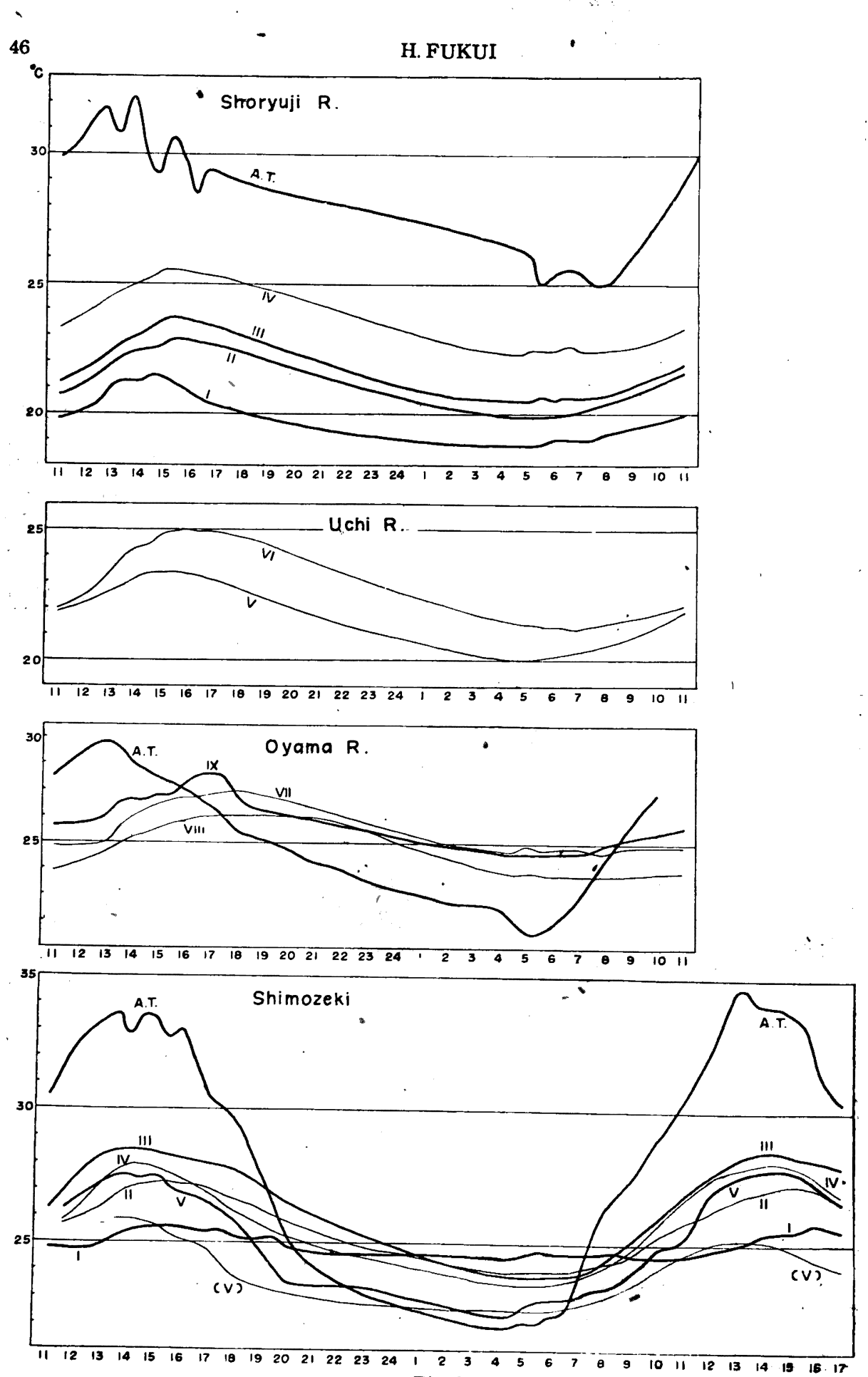

Fig. 2 

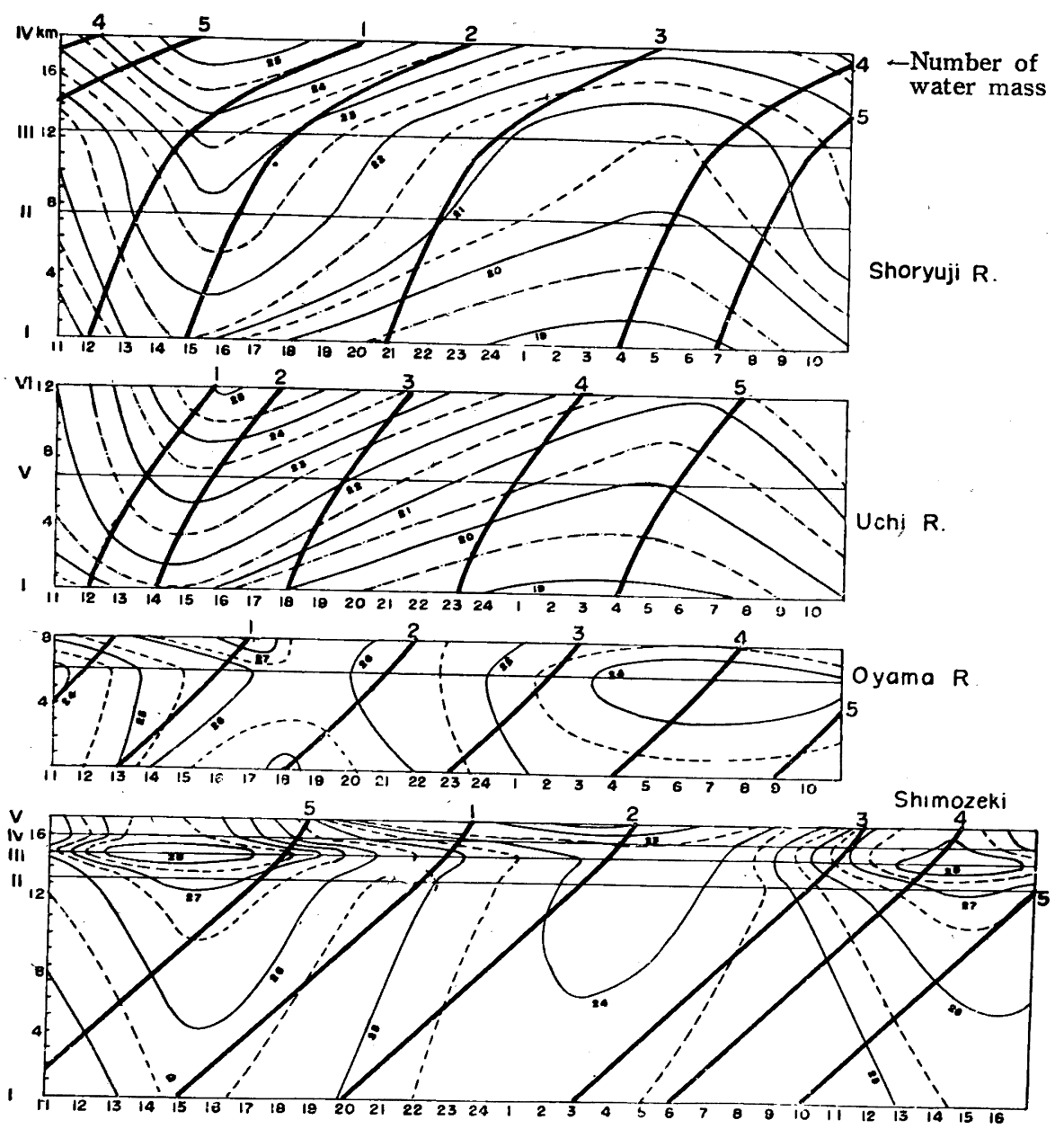

Fig $3 \mathrm{X}$-axis indicates a distance from the sluice gate and $\mathrm{Y}$-axis a time

the point is located, the wider the daily range is, but Point III shows the same value as Point IV. (e) The change in water temperature which a water mass shows as it passes every point downwards is read in Table II, written based on Fig. 5. That is, no decline is observed in every part among the points and the temperature seems to continue to rise in the whole length of the water-way. As to the rising rate (the value raised per $10 \mathrm{~km}$ a mass of water covers) the lower the point is situated, the higher its highest value is. But, in the case of the Uchi river, the lower the point is located, the lower its lowest value is, while, in the case of the Shoryuji river, the upper the point is, the lower its lowest one is. (f) Violent turbulent motions, which 

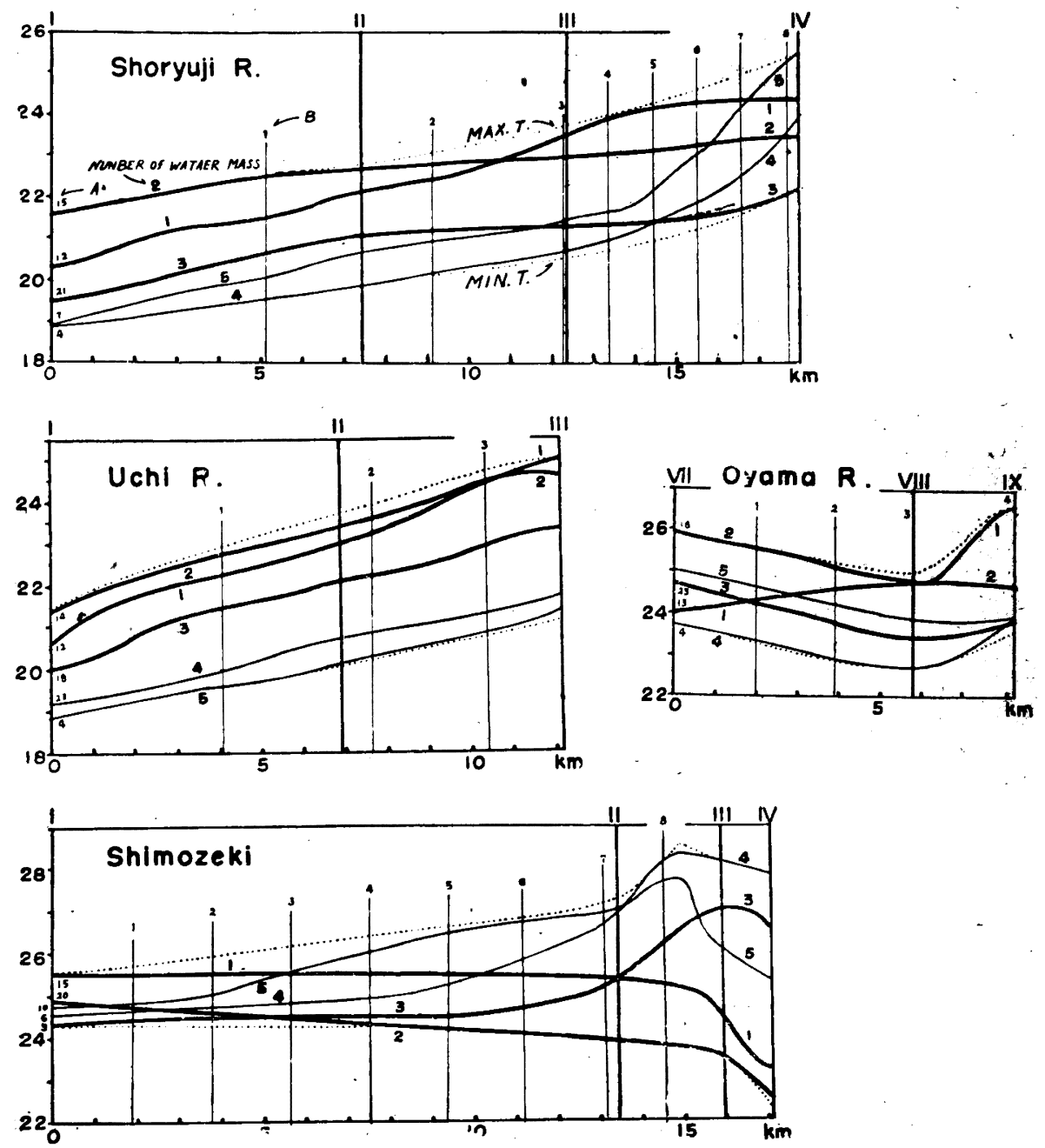

Fig. $4 \mathrm{X}$-axis indicates a water temperature and $\mathrm{Y}$-axis a distance from the sluice gate.

A: Time when water mass passes at Point I.

B: Time when water spend since the time (A)

have a close relation with raising water temperature, ought to be expected in the upper part, but the rising rate is higher in the lower reaches. This seems due to the decrease in the quantity of running water in the downstream. (g) But the highest and lowest values in the rising rate do not always coincide with those in the air temperatures, and further, as is the case with the part between Point II and Point III, the value of the rising rate shows 0 , though the air temperature is always higher than the watet temperature during the 

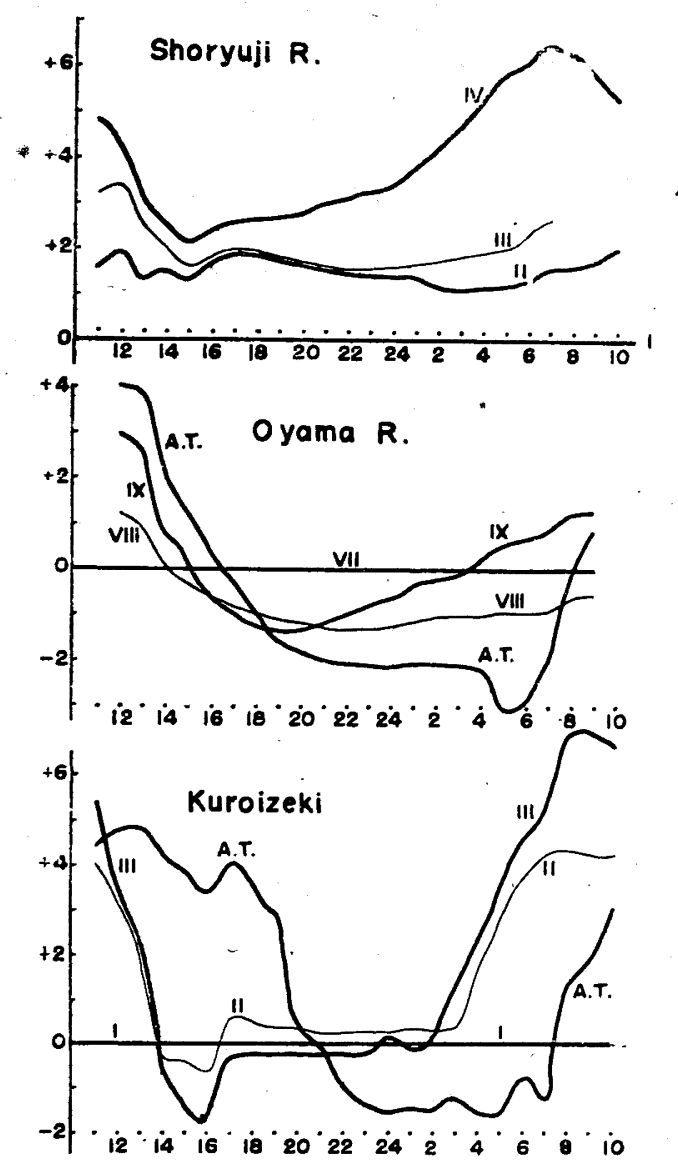

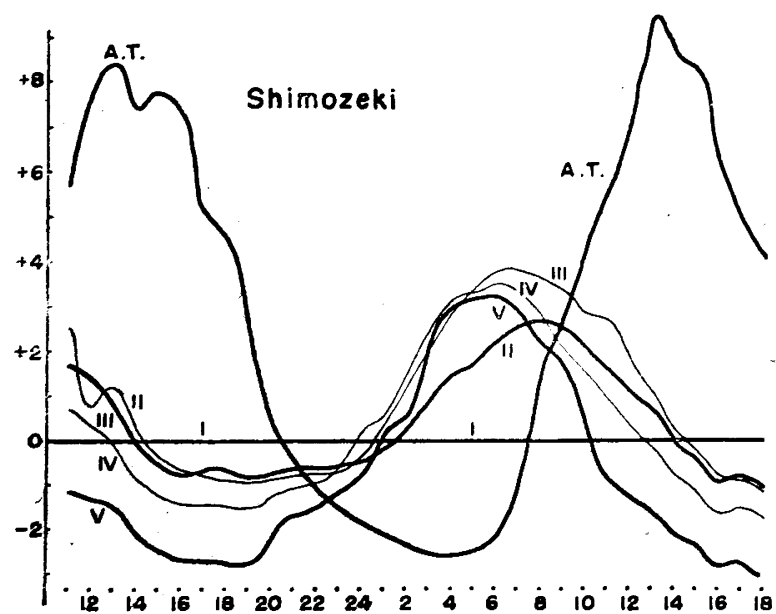

Fig. 5 time. This is probably influenced by the water flowing in, considering the fact that the highest value appears later in the lower part as is read in the case of $(b)^{(2)}$ theoretically, there must be coincidence in the time when the minimum temperature appears between the two points in the uppermost and lowermost parts. (h)The Uchi river clearly shows the higher value of the rising rate. This is because the discharge of the one is different from that of the other.

2. The Oyama river (a) The daily changes at Points VII and VIII show a very gentle curve, while that at Point IX indicated a rapid rising and falling. (b)Consequently, the maximum temperature appears earliest and clearly at Point IX, but it continues from 17.5 to $18.5 \mathrm{~h}$ at Point VII, and from $17 \mathrm{~h}$ to $20 \mathrm{~h}$ at Point VIII. (c) An extraordinary phenomenon is noted that the maximum and minimum temperatures are

(2) The irrigation water of paddy-fields flowes scarcely in, because the observation was carried on at the irrigation period. But the paddyfields situate on the percolative fan and the irrigation water of paddy-fields seems to flow in as a ground water. 


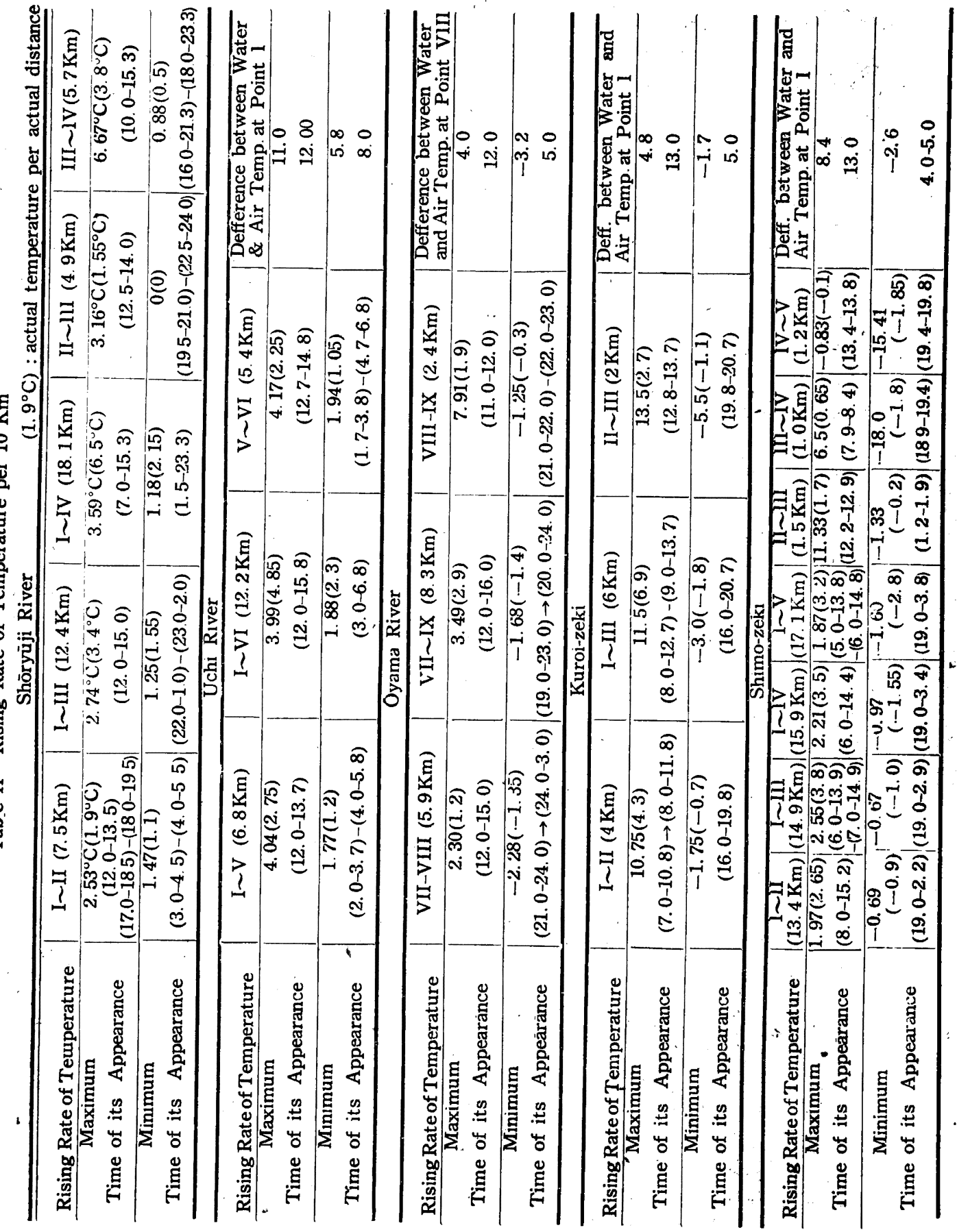


both the lowest at Point VIII. The maximum temperature is highest at Point IX, and the minimum ones at Point VII and IX show the same value. (d) But the points in the lower reaches show wider daily ranges. (e) Concerning the change in temperature a water mass shows when it runs between Point VII and VIII, an incessant decline is observed during the time 'between a water mass passing Poing VII at $15 \mathrm{~h}$, and reaching. Point VIII at $18 \mathrm{~h}$ (here after the water mass will be named " $15 \sim 18 \mathrm{~h}$ " mass and like this.), and the "9$12 \mathrm{~h}$ " water mass, and the period of rising is very short. (f) And, the rise can be noted except the " $19 \sim 20 \mathrm{~h}$ " and " $24 \sim 1 \mathrm{~h}$ " water masses in the part between Point VIII and IX. (g) That is to say, there is a rise in temperature during the time when the air temperature is lower than the water temperature between Point VIII and IX, and a decline during the time when it is higher between Point VII and VIII. This is also probably due to the water flowing in between Point VII and IX, just as in the case of the Shoryuji river. And the phenomenon like (c) seems to have been brought about, because the influence is remarkable in this river than in the shoruji river. ${ }^{(3)}$

3. Kuroi-zeki(t) (Kuroi canal) (a) The temperature at Points I and III declines like steps from its peak, according to the curve of the daily change, but that at Point II shows a gentle decline. (b) The maximum temperature is lower at Point II than at any others, while it is the highest at Point III, (similar to that in the Oyama river), the minimum' one being higher in the lower part. (c) The maximum temperature appears earliest at Point I and latest at Point II (similar to that in the Shoryuji river), and the minimum one likewise comes latest at Point II and seems to appear nearly at the same time at Points I and II. But the time when the minimum temperature is recorded, is clearly observed at the two points, though it is not obvious along. the Shoryuji and Oyama rivers. (d) The daily range is generally wide (9.4, 7.5 and $7.1^{\circ} \mathrm{C}$ ), and the values grow less in accordance with the distance from the upper point. This phenomenon is also inverse to that in the case of the former two water-ways. (e) Concerning the temperatures the water masses show in passing the points, those-from the " $14-17.8 \mathrm{~h}$ " water mass to the "16-19.8 h" one-show a decline between Points II and III. (f) The temperature beging to fall even during the time when the air temperature is higher than the water temperature, and it has already passed the maximum value of decline at the time when the former nearly coincides tne latter. That is to say, it sometimes happens that the minimum and maximum water

(3) The water surface of water-way is $3 \sim 4 \mathrm{~m}$ lower than the paddy-fields of both side areas, and in the case of the River Shoryuji, $1 \sim 3 \mathrm{~m}$.

(4) The general feature was reported by Prof. Y. Tomita in the following papers. "Hydrography and Irrigation System in the Yonezawa Basin" Sci. Rep. Tôhoku Uni. (geography) No. 5, pp. 23-26, 1956 
temperatures are not concident with those of the air. This is also due to the water flowing in, which the increase in the quantity of the running water between Points I and II suggests ${ }^{(b)}$ (g) But the fact mentioned in (a)-(d) seems to have a relation with the change in river water temperature at Point $I$.

4. Shimo-zeki (Shimo canal) (a) In general, the curve of the daily change shows a tendency to rise abruptly. and fall gently, but it varies like steps at Point V. (b) The minimum temperature gradually declines from upper to lower, while the maximum temperature grows higher to Point III, and shows low values at Point IV and Point V. (c) As a result of conducting its water out of the dam, the daily range at Point $I$ is small, and the widest at Point V. ${ }^{(6)}$ (d) Moreover, the time when the maximum temperature appears is the latest at Point I, earlier to Point III, and later at Point IV and V again. (e) According to the rising rate throught out the points, it falls between Points III and $\mathrm{V}$, showing in relation to the air temperature. This is because it is influenced by the cold water flowing in out of the cliff of the upland, as the increase in the discharge from Point III to Point V suggests ${ }^{(7)}$. (f) The maximum rising rate of temperature is larger in proportion to the distance from the upper point, while the minimum one is smaller between Point I and Point II and also Point II and Point III, on account of the decrease indischarge. ( $\mathrm{g}$ ) The maximum is shown by the water mass which passes Point I at the time of the lowest air temperature, and arrives at every point at the time of the highest one, the minimum temperature shown by the " $19-4$ " $h$ " water mass.

Considering the water temperatures of the above four water-ways, the following can be pointed out. (a) The actual state of water temperature is able to be grasped through the idea of a water mass to understand the change in the water temperatures of water-ways, (b) though the time spent in its passing must be correctly caught. (c) The water flowing in is pointed out as one of the most powerfull factors that bring about the change in the water temperature, considering the rising rates got based on the surmised water velocity. (d) Considering the minimum rising rate of ten appearing at 17-24 $h_{3}$ the influence of the water flowing in seems to have a complicated relation to the changes of its quantity and temperatures. (e) That is to say, the influence is comparatively weak in the Shoryuji river, which shows the lowest temperature,

(5) No surface waters flow in and no branched water-ways are recognized between Point 1 and $\mathrm{Il}$.

(6) The relation between the temperatures of the dam water and the branched water will be given in the next chapter.

(7) The hight of the cliff is over $5 \mathrm{~m}$ at Point IV and over $15 \mathrm{~m}$ at Point V. The curve (V) in Fig. 2 shows the temperature of the water flowing in out of the cliff near. Point IV. 
and is, on the contrary, remarkable in the three others whose water temperatures are warmer. This is, of course, due to the position and structure of the waterways.

\section{Annual changes in the river water temperature}

It is generally recognized that water temperature exercises greater influence - over the growing of rice-plants 40 or 5 days before their head sprouting. That is to say, it will be given a fatal blow, if the water temperature is lower than $20^{\circ} \mathrm{C}$; it is in proportion to the temperature, if it is between $20^{\circ} \mathrm{C}$ and $25^{\circ} \mathrm{C}$; stignant if it is between $25^{\circ} \mathrm{C}$ and $32^{\circ} \mathrm{C}$; and damahed by high temperature if higher than $32^{\circ} \mathrm{C}^{(8)}$. As the head sprouting period is in the beginn-

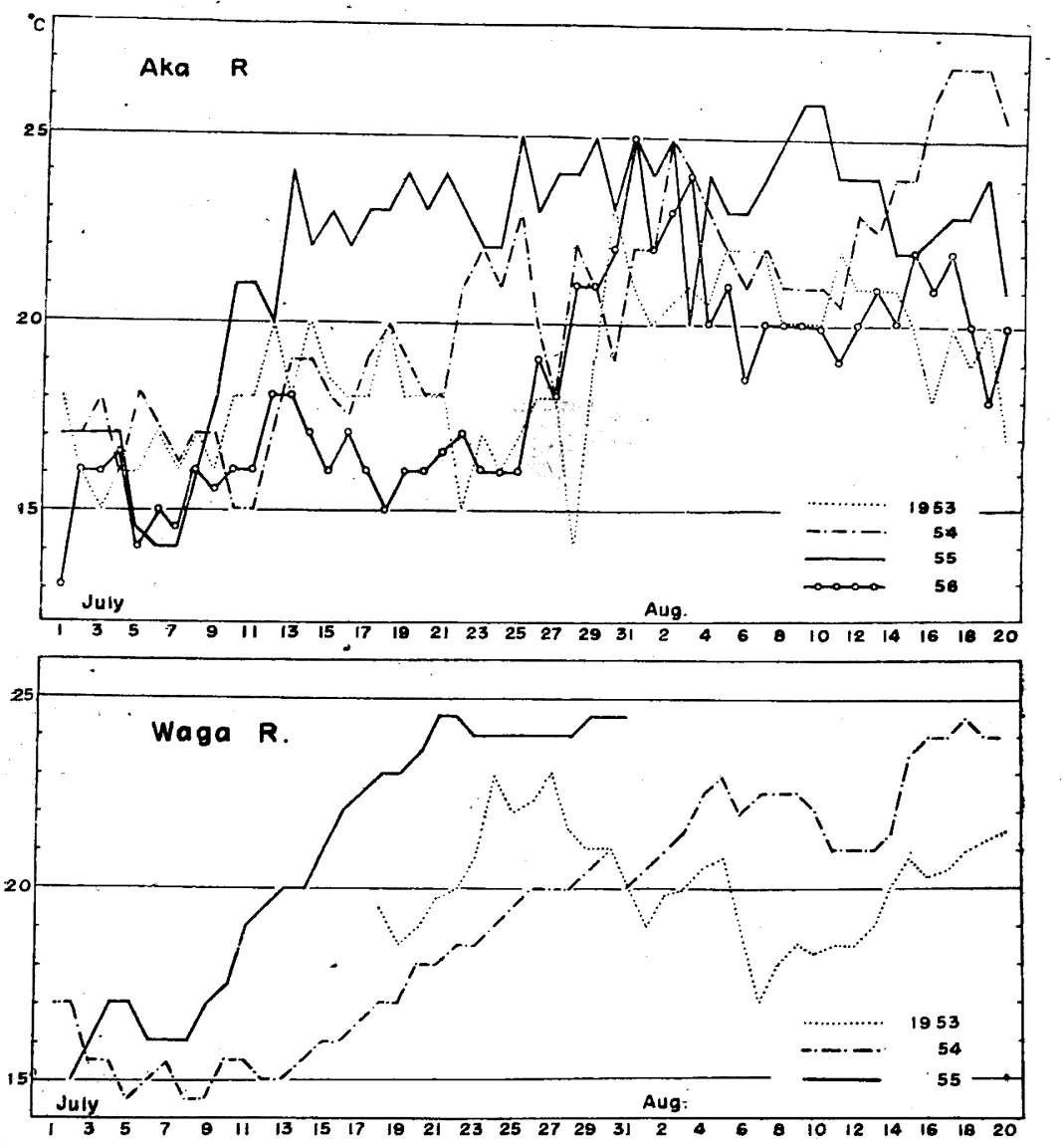

Fig. 6

(8) Ass. Agr. Met. J. : On the literatures of the damage to rice plant by a cold water pp. $40-42,1955$. 
ing or middle part of August in the nighbouring area to the surveyed waterways, the author is going to consider the water temperatures between July 1 and August 20.

According to the results got at $17 \mathrm{~h}$ during '53 '56 at the sluice-gate in the case of the Shoryuji river $^{(9)}$ (Fig. 6); a change can be observed from 22 ('53) to 42 ('55) in the number of days showing higher values than $20^{\circ} \mathrm{C}$, and, concerning the mean water temperature, it changes from $18.4^{\circ} \mathrm{C}$ to $21.6^{\circ} \mathrm{C}$ showing the difference of $3.2^{\circ} \mathrm{C}$. The rise of the water temperature in the water-ways mentioned above, took place under the best weather condition. And it rose by $1.9 \sim 1.1^{\circ} \mathrm{C}$ at Point II, and by $3.4 \sim 1.4^{\circ} \mathrm{C}$ even at Point III. The difference is so small that if the water temperature of river and air temperature decline, it naturally follows from it that the rising rate becomes much smaller. Thus, especially in the drainage area between Point I and Point III, appears the phenomenon of damages by cold water at the time when the temperature of river water goes down as it did in '53. Fig. 7 shows the relation between the mean temperature of river water and the mean yield of rice per tan among those of three villages ${ }^{(10)}$ in the area irrigated by means of thes water-ways, clearly indicating a direct propertion between these two elements.

Shimo-zeki is a water-way conducted from the Ishibana Dam by means of a fixed sluice gate, so that the temperature of the surface water of the dam is different from that of the water-way. According to Fig. 8, which shows the vertical temperature distribution of the dam (at the time of full water), the location of the sluice-gate and the water temperature at the gate, the water discharged from the gate shows $24.85^{\circ} \mathrm{C}$, which corresponds to the temperature at the depth of $2.4 \mathrm{~m}$, the value is $11.65^{\circ} \mathrm{C}$ less than that on the surface ${ }^{(11)}$.

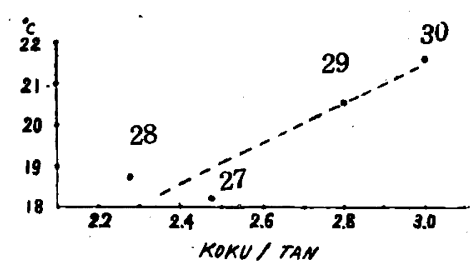

Fig. 7

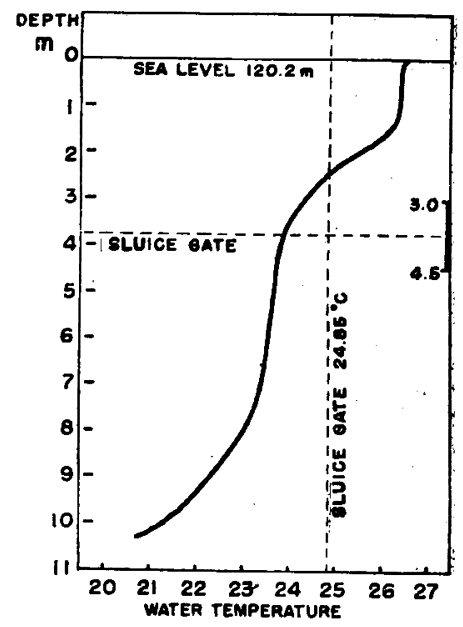

Fig. 8 Observation from $15 \mathrm{~h}$ to $16 \mathrm{~h}, 4$ th, Aug. 1955. Air temp. $29.9^{\circ} \mathrm{C}$, fine. Consequently, it follows from this that the daily change of temperature at

(9) According to the data obtained by the Division of Socil Improvement of the R. Shōryūji. The water temperatures at $17 \mathrm{~h}$ nearly coresponds to the mean daily temperatures.

(10) Sai, Yamazoi and Kogane-Mura

(11) By the author's observation. 
Point I is less when the level of the dam water is higher, and more when it is lower. And according to the annual change in the water temperature at Point I at $9 \mathrm{~h}^{(13)}$ (Fig. 7), it shows aearly the same process as the Shoryuji river present. The change in the rising rate, in the case of Shimo-zeki, is 2.6 $\sim-1.0^{\circ} \mathrm{C}$ at Point II $3.5 \sim-1.8^{\circ} \mathrm{C}$ at Point III, and $3.2 \sim-2.8^{\circ} \mathrm{C}$ at Point $\mathrm{V}$, on the condition of fine weather, so that if it is lower than $20^{\circ} \mathrm{C}$ at point I, anb, in addition, the low air temperature continues, then cool damages will be naturally done in its drainage area. Especially in '53, rice wilting disease was prevalent in the whole area of this river system, and this fact clearly indicates a close relation between the water temperature and the damages caused by it $^{(13)}$.

In conclusion

As one of the method of study on the district suffered from the cool dmage, it is neccesary to grasp the relation between the temperature of river or irrigation water and the geographical conditions. The observations presented in this paper are only a preliminary study, but, of course, the systematic study must be done in future. The author wishes to express grateful appreciation to Prof. Yoshiro Tomita under whose supervision the present work has been carried out.

(12) According to the data obtained by the Division of Soil Improvement of the Kurosawajiri. The water temperature at $9 \mathrm{~h}$ seems to be somewhat lower than the mean daily temperatures.

(13) Iwate Pref. On the actual state of the damage of rice plant by the cool weather in 1953. p. 151951. 